УДК 007:304:004.9

\title{
СОЦІАЛЬНІ КОМУНІКАЦІЇ \\ В ГЛОБАЛЬНІЙ ІНФОРМАЦІЙНІЙ МЕРЕЖІ: ДОСЯГНЕННЯ І ЗАГРОЗИ
}

( П. О. Киричок, д.т.н., професор, НТУУ «КПІ», Київ, Україна

\author{
Рассмотрены особенности коммуникативного \\ взаимодействия в Интернете, выделены элементы интернет- \\ коммуникации. Проанализированы потенциальные \\ опасности для пользователей сети.
}

Features of communicatory interaction within Internet are investigated; elements related to internet communication are picked out. Potential threats for Internet users are analyzed.

\section{Постановка проблеми}

Чи не найпоширенішим засобом соціальної комунікації в сучасному глобалізованому світі стала мережа Інтернет. Важливою її перевагою $є$ те, що завдяки необмеженому доступу вона надає можливість групам осіб, які в реальному житті навряд чи об'єдналися б (передусім через територіальну розпорошеність), провадити спільні дії, дистанційно вирішувати актуальні проблеми. Інтернет-комунікація $€$ новітньою формою взаємодії людей у сучасному суспільстві. ї̈̈ роль особливо актуалізується в контексті сучасних глобальних загальноцивілізаційних процесів, коли активізується поширення по всій планеті єдиних, спільних для всього людства технологій, культур, ідей, ціннісних орієнтацій, способів життя, поведінки, тобто відбувається становлення єдиного комунікаційного простору.

Інтернет значно змінив характер діяльності журналістів як професійних комунікаторів. Вони дедалі рідше створюють «нову» інформацію й зазвичай стають ретрансляторами інформації, розміщеної в Інтернеті, модераторами інформаційних потоків. Ця їхня функція особливо важлива за умов сучасної інформаційної кризи, коли людство захлинається в потоці інформації. «Ми породили на світ скільки статистичних даних, формул, образів, документів і декларацій, що не в змозі їх осмислити, і замість того, щоб шукати нові шляхи осмислення і засвоєння вже створеного, ми далі ще швидшими темпами виробляємо нову інформацію», - стверджує А. Гор [1, С. 94].

На редактора мережевий інформаційний простір, котрий перенасичений подіями та явищами, потоком суперечливих думок, покладає виконання ролі штурмана, котрий визначає, який матеріал та 3 якою інто- 
нацією подавати спільноті. Щоденне зростання темпів продукування інформації вимагає 3 максимальною ефективністю та швидкістю осмислювати нове знання та встановлювати причиново-наслідкові зв'язки.

\section{Аналіз попередніх досліджень}

Щодо досліджень мережевого спілкування, то в Україні Інтернет як сучасний вид комунікації вивчали О. Мелещенко, О. Панагушина. В. Різун, О. Чекмишев, В. Іванов, О. Калмиков, М. Лукіна, І. Фомічева та ін. Проте, з огляду на більш раннє поширення Інтернету в США та країнах Західної Європи варто констатувати, що критична маса наукових публікацій 3 означеного напряму припадає саме на ці регіони.

\section{Мета роботи}

3'ясувати особливості комунікативної взаємодії в Інтернеті та сформулювати правила безпечного користування мережею.

\section{Результати проведених досліджень}

Інтернет запропонував не лише швидкий пошук інформації, а й, насамперед, надав нові можливості для спілкування. Комунікативна взаємодія в Інтернеті може відбуватися як у режимі реального часу (чати, рольові ігри), так і з затримкою відповіді (веб-форуми, блоги, гостьові книги, електронна пошта).

у сучасному суспільстві змінюється сама культура споживання інформації: значна частка молоді віддає перевагу електронним ресурсам, доступним 3 мобільних гаджетів. Такі платформи, як Twitter, Skype, Facebook, ВКонтакте дають змогу долати географічні, культурні, майнові бар'єри.

Інтернет-комунікація містить такі елементи:

- автор та споживачі повідомлення;

- саме повідомлення як носій інформації;

- канал комунікації, за допомогою якого підтримується зв'язок адресанта та адресата;

- фактори, що перешкоджають та спотворюють передачу інформації (перебої в роботі мережі, спам, флуд, тролінг тощо);

- фільтри-обмеження, що накладаються на інформацію при відборі людиною інформації для сприйняття з урахуванням не лише її фактичного змісту, але й власної позиції.

На нашу думку, можна виокремити такі переваги мережевої комунікації:

1) інтерактивність, тобто наявність зворотного зв'язку;

2) використання можливостей мультимедіа - кількох способів подання інформації: текст, статична ілюстративна частина, динамічна ілюстративна частина та звук;

3) простота й оперативність оновлення матеріалу, а також 
висока швидкість, 3 якою ці зміни передаються користувачам;

4) можливість копіювати та роздруковувати текст; архівувати та каталогізувати матеріал у великому обсязі;

5) можливість отримати розширену інформацію завдяки гіперпосиланням;

6) розвинений пошуковий механізм.

Для Інтернету характерні всі функції, що їх виконують засоби масової комунікації в суспільстві: інформування, вплив на становлення громадської думки, мотиваційна, рекреаційна. Характерною особливістю спілкування в Інтернеті $€$ анонімність, необмежена доступність контактів, висока швидкість поширення інформації, діалогова форма комунікації.

І якщо на початкових стадіях розвитку Інтернету мова йшла лише про дистанційне спілкування, то з появою веб камер і програм передавання звуку та відео в режимі он-лайн уже можна говорити, що Інтернет надає своїм користувачам можливість безпосереднього, контактного спілкування. До того ж, імітувати невербальне спілкування в Інтернеті дають змогу так звані «смайлики» - певні поєднання знаків пунктуації, які відповідають емоціям людини в реальному житті. Існують також спеціальні набори смайликів. Більшість з них - це стилізовані зображення обличчя, яке виражає різні емоції: усмішку, стурбованість, злість тощо.

Мережа Інтернет трансформує способи спілкування, коре- лює міжособистісні взаємини, дозволяє жити у самоствореному міфічному світі, де не існує поділу за расовими, національними, релігійними, віковими, статевими, фізичними та іншими ознаками. Незліченна кількість мотивацій спонукає молодь до змістовного наповнення інформаційних потоків, організації активних аудиторій, здатних оцінити їх ініціативи, розширити коло контактів [2].

Варто зазначити, що Інтернет - це ще й електронна комерція, де належне місце посідає електронна торгівля; потужні пошукові системи; електронна преса; дистанційні освітні ресурси; різноманітні мережеві розваги. Інакше кажучи, сучасний Інтернет дає можливість працювати, навчатися, проводити дозвілля. Нові електронні засоби комунікації проникають у глибинну внутрішню природу людини, коригують взаємини в суспільстві та, на думку Б. Гейтса, забезпечують людям можливість робити покупки, дізнаватися про новини, зустрічатися, розважатися і пліткувати різноманітними засобами. При цьому Інтернет стає центральним майданчиком всесвітнього села завтрашньої днини [3].

Однак не обходиться тут і без численних порушень мережевого етикету, до яких передусім належать:

- спам-повідомлення, що їх надсилають невідомі люди без згоди адресата. У великій кількості спам істотно заважає працювати з особистою корес- 
понденцією. Деякі компанії, ведучи цілком легальний бізнес, $з$ допомогою спаму рекламують свої товари та послуги. Така маркетингова стратегія не потребує значних витрат і водночас дає змогу охопити значний масив потенційних клієнтів. Нерідко спам використовується для реклами забороненої законом продукції: порнографії, контрафактних товарів (наприклад, підробок, творів, комп'ютерних програм, баз даних, виготовлення або поширення яких призводить до порушення авторських чи суміжних прав);

- флейм - «словесна війна», скандалізм, коли учасники дискусії відхиляються від основної теми обговорення й переходять на взаємні провокації, образи та звинувачення. Зазвичай основою флейму стає політична, релігійна та національна ворожнеча. Флейм буває різних рівнів - від примітивної нецензурщини до застосування гострої сатири і єхидної критики;

- тролінг - психологічний тиск 3 метою викликати негативні емоції, агресію, розміщення провокаційних повідомлень для того, аби розпалити конфлікти між учасниками обговорення. Мета тролінгу втягнути учасників полілогу в безглузду конфронтацію, викликати сварку й нестримні потоки негативних емоцій, які $€$ своєрідною «їжею» для тролів. Недаремно в інтернет-культурі нерідко використовується фраза «Do not feed the troll» (He roдуйте тролів);
- флуд - навмисне захаращування форумів і чатів повідомленнями, що не стосуються теми обговорення. Флудом $є$ як короткі, так і дуже довгі повідомлення, які заважають читати тему, беззмістовні репліки, кілька повідомлень, розміщених одне за одним, тощо. На відміну від спаму, флуд зазвичай не несе жодної рекламної інформації;

- офтопік - поодинокі повідомлення не за темою поточного обговорення чи поштової розсилки;

- капс - зловживання використанням великих літер.

Проблемами мережевої комунікації можна вважати часте порушення літературних норм, діяльність фінансових шахраїв, хакерів, різного роду дезінформаторів, наявність відкритої пропозиції послуг порноіндустрії. Ускладнюються ці недоліки ще й тим, що активними учасниками електронних комунікацій на сьогодні стали діти, юнацтво, а також люди похилого віку, які, втративши пильність, стають жертвами «інформаційного насильства». Інтернет містить численні картинки й відеооролики зі сценами жорстокості й порнографії, дає інформацію про місце та способи придбання наркотиків, про технологію скоєння злочинів тощо.

Дедалі масовішими стають випадки, коли на електронну пошту, на персональні веб-сторінки в соціальних мережах приходять повідомлення з проханням надіслати гроші на вказану адресу, узяти участь в яко- 
мусь загадковому голосуванні або, скажімо, зайти на дуже цікаву сторінку в Інтернеті. Нерідко приходять листи нібито від офіційних установ (банків, страхових компаній, відомих фірм), в яких під привабливим для адресата приводом вимагають надати конфіденційну інформацію: адресу, телефон, а нерідко й номер карткового рахунку, та ще й разом з PIN-кодом.

Самі учасники соціальних мереж «ВКонтакті», «Однокласники» та їх аналогів іноді без вагань розміщують на своїх сторінках особисту контактну інформацію - номери телефонів, адреси, що вкрай небезпечно, адже дані можуть бути використані зі злочинними намірами. До того ж, в Інтернеті зростає загроза розкриття державної таємниці, масового поширення недостовірної інформації тощо.

Узагальнюючи досвід користування Інтернетом, можна сформулювати цілком очевидні правила безпеки користування мережею:

- ніколи й за жодних обставин не надсилати нікому свій логін і пароль;

- не давати невідомим людям свої прізвище; ім'я та по батькові, реальну адресу, домашній і робочий телефони;

- не запускати файли, отримані з ненадійного джерела.
Навіть якщо файл надійшов зі знайомої адреси, але несподівано і лист має доволі дивний зміст, то варто зв'язатися 3 відправником і поцікавитися, чи справді він надсилав такий файл;

— зайвий раз не «ходити» по невідомих посиланнях;

- не тримати на комп'ютері справді серйозних конфіденційних даних або зберігати їх у зашифрованому вигляді під захистом паролів;

- використовувати оновлюваний антивірус.

\section{Висновки}

Отже, мережа Інтернет принципово змінила уявлення про засоби комунікації, зумовила поширення в соціумі нових форм комунікативної поведінки. Вона об'єднала в собі інтерактивний характер комунікації, гіпермедійність і можливість зворотного зв'язку. Нині новітні комунікації змінюють суспільство, формують нові цінності, етичні норми, настанови.

Водночас всесвітня павутина виявилася джерелом численних потенційних небезпек для користувачів, а тому не може визначатися як однозначний позитив. Саме тому довгостроковою стратегічною метою має стати вироблення наукових підходів до вивчення й осмислення феномену комунікації у всесвітній мережі. 
1. Ленем Р. Електронне слово. Демократія, технологія та мистецтво / Річард Ленем ; пер. з англ. А. Галушка. - К. : Ніка-Центр, 2005. - 376 с. 2. Прохоренко Е. Я. Феномен киберкультуры в информационнотехнологическом воспроизводстве социума : дис. канд. социол. наук : 22.00.04 / Е. Я. Прохоренко. - Одесса, 2008. - 215 с. 3. Гейтс Б. Бизнес со скоростью мысли / Б. Гейтс. - Изд. 2-е, исправл. - М. : Изд-во ЭКСМО Пресс, 2001. - С. 127.

1. Lenem R. Elektronne slovo. Demokratija, tekhnolohija ta mistetstvo / Richard Lenem ; per. z anhl. A. Halushka. - K. : Nika-Tsentr, 2005. - 376 s. 2. Prokhorenko E. Ja. Fenomen kiberkul'turi $v$ informatsionno-tekhnolohicheskom vosproizvodstve sotsiuma : dis. kand. sotsiol. nauk : 22.00.04 / E. Ja. Prokhorenko. - Odessa, 2008. - 215 s. 3. Heits B. Biznes so skorost'ju misli / B. Heits. - Izd. 2-e, ispravl. - M. : Izd-vo EKSMO - Press, 2001. S. 127. 